\title{
Potassium mobilization and plant growth promotion by soil bacteria isolated from different agroclimatic zones of Odisha, India
}

\author{
Aiswarya PANDA ${ }^{1,2}$, Ankita DASH ${ }^{1}$ and Bibhuti Bhusan MISHRA ${ }^{1}$
}

Received July 24, 2020; accepted July 21, 2021. Delo je prispelo 24. julija 2020, sprejeto 21. julija 2021

\begin{abstract}
Potassium mobilization and plant growth promotion by soil bacteria isolated from different agroclimatic zones of Odisha, India

Abstract: Potassium is essential for plant metabolism; improves immunity to stress and increase crop productivity. Soil contains insoluble form of potassium, which is unavailable for plant absorption. Potash mobilizing bacteria (KMB) solubilise complex potassium and make it available to plant. KMB with plant growth promoting (PGP) traits could enhance growth and crop productivity. Here we attempt to screen KMBs with PGP traits from different agroclimatic zones of Odisha and study dynamics of potassium in soil. Isolation of $\mathrm{KMB}$ and determination of PGP traits was performed with standard protocols. Pot culture experiment was aimed to study their effect on sunflower crop. Available soil potassium was quantified using inductively coupled plasmaoptical emission spectrometry (ICP-OES). Thirty KMBs were isolated from different agro-climatic zones of Odisha, out of which 6 isolates exhibited maximum PGP traits. Moreover, after adding inoculums the available soil potassium decreased over 0 to 30 days as compared to control, with increase in shoot length. T7 (consortium) reported maximum (144 \%) increase in shoot length. Available soil potassium content decreased with increase in time. A maximum decrease was reported in T7 (26.31\%), suggesting potassium accumulation by plant.
\end{abstract}

Key words: soil; potash mobilizing bacteria; plant growth promoting rhizobacteria; soil potassium; potassium availability
Mobilizacija kalija in pospeševanje rasti rastlin s talnimi bakterijami, izoliranimi iz različnih agroklimatskih območij Odishe, Indija

Izvleček: Kalij je nujno potreben element $\mathrm{v}$ presnovi rastlin. Izboljšuje odpornost na stres in povečuje pridelek. Tla vsebujejo netopne oblike kalija, ki ni dostopen rastlinam. Kalij sproščajoče bakterije (KMB) raztapljajo vezan kalij in ga naredijo dostopnega rastlinam. KMB bi skupno s snovmi, ki izboljšujejo rast lahko povečale rast in pridelek. $\mathrm{V}$ raziskavi poskušajo preveriti KMB z PGP lastnostni iz različnih agroklimatskih območij Odishe in preučiti dinamiko kalija v tleh. Izolacija KMB in določitev njihovih PGP lastnosti sta bili izvedeni s strandardnimi protokoli. Izveden je bil lončni poskus za preučitev njihovega vpliva na pridelek sončnic. Razpoložljiv kalij v tleh je bil določen $\mathrm{z}$ ICP-OES protokolom. $\mathrm{V}$ različnih agroklimatskih območjih Odishe je bilo izoliranih $30 \mathrm{KBM}$, od katerih je 6 izolatov pokazalo največje vrednosti PGP. Po dodatku teh inokulumov se je razpoložljiv kalij v tleh zmanšal v 30 dneh v primerjavi s kontrolo s hkratnim povečanjem dolžine poganjkov. T7 inokulum (consortium) je dal največje povečanje (144 \%) v dolžini poganjkov. Vsebnost razpoložljivega kalija $\mathrm{v}$ tleh se je zmanjševala s časom poskusa. Največje zmanjašanje je bilo zabeleženo pri uporabi inokuluma T7 (26,31 \%), kar kaže na kopičenje kalija v rastlinah.

Ključne besede: tla; kalij sproščajoče bakterije; rast vzpodbujajoče rizobakterije; talni kalij; razpoložljivost kalija

1 P.G.Department of Microbiology, College of Basic Science \& HumanitiesOdisha University of Agriculture and Technology, Bhubaneswar- 751003; Odisha, India

2 Corresponding author, email: aiswaryapanda95@gmail.com, telephone: +91-8895676576 


\section{INTRODUCTION}

Potassium (K), a vital macro-nutrient absorbed by plants from the soil, which enters into the food chain to meet requirement of animals including human (Morgan and Connolly, 2013). Soil mostly contains complex insoluble forms of potash like biotite, feldspar, mica, sylvite, etc. and unavailable for plant uptake. Deficiency of potassium in plants leads to scorching and curling of leaf tips, chlorosis between leaf veins, reduced root, leaf size and seed \& fruit development (Uchida, 2000). Generally, Potassium is considered the most abundant of the major soil nutrient elements. In soil the total $\mathrm{K}$ content ranges from $0.01 \%$ to $4 \%$, usually about $1 \%$ (Sparks, 1987; Blake et al., 1999). The average soil K value for production of corn is $71-130 \mathrm{ppm}$ and alfalfa 71-140 ppm. The average soil test $\mathrm{K}$ content of coarsetextured soil is $103 \mathrm{ppm}$ and for medium and fine textured soil is $128 \mathrm{ppm}$ (Peters, 2011), needs application of potassium fertilizer. Due to imbalanced use of NPK fertilizers and intensive cropping system, widespread deficiency of $\mathrm{K}$ is observed in Indian soil (Naidu et al., 2011). At national level, potassium depletion in Indian soil was approx. $10.2 \mathrm{t}$ year ${ }^{-1}$. In Odisha, soil $\mathrm{K}$ content was 36.7- 458.3 $\mathrm{kgha}^{-1}$ against the required amount of $110-280 \mathrm{kgha}^{-1}$. Although soil is rich with potassium, about $90-98 \%$ is chemically bound in the crystal lattice structure of the minerals and unavailable for plant uptake (Gurav et al., 2019). Odisha has 10 agroclimatic zones (Mishra and Mishra, 2016). Total K content of Odisha soil ranges between 0.3 to $3.0 \%$ of which non exchangeable $\mathrm{K}$ comprises 21-61 \% and exchangeable $\mathrm{K}$ constitue 12.5-35.7 \% (Jena et al., 2009).

Replacement of potassium through chemical fertilizers significantly imposes threat to environmental safety and sustainability by leaching, soil \& water pollution, susceptibility of crop to diseases (Perez-Lucas et al., 2018). High percentage of $\mathrm{K}$ in chemical fertilizers also causes longterm imbalance in soil $\mathrm{pH}$ affecting fertility. Soil is a habitat for multitudinous microbial population (Nayak et al., 2020). Microbial conversion of insoluble $\mathrm{K}$ into soluble form by potassium mobilizing bacteria (KMB) can enhance availability of soluble $\mathrm{K}$ for plant uptake. Many predominantly soil bacteria such as, $B a$ cillus circulans (Jordan, 1890), B. mucilaginous (Avakyan et al., 1986), Paenibacillus spp. (Ash et al., 1994) etc. are known to readily solubilise K minerals. Potassium mobilizers dissolve the complex silicate minerals to release soluble $\mathrm{K}$ through various mechanisms like chelation, production of inorganic and organic acids, acidolysis, polysaccharides, exchange reactions, also produce exopolymeric substances (Bhattacharyya and Jha, 2012) to solubilise element. These potential bacteria can be bet- ter utilized as biofertilizer in recycling and biofortification of potash in crop fields. Raghavendra et al. (2016) and Zahedi (2016) opined, biofortification of essential nutrients through microbes is an effective measure to overcome macro \& micro-nutrient deficiency in growing cereal crops; with maximum levels of bioavailable nutrient concentration and subsequently eliminating nutrient deficiency in plants and animals (Saravanan et al., 2011).

Plant growth promoting rhizobacteria are the group of microbes having the ability to promote growth of the plants by several direct mechanisms (nitrogen fixation, phytohormones production, phosphate solubilisation, siderophore production etc.) and indirect mechanisms (antibiotic production, lytic enzymes production, induced systemic resistance (ISR), HCN production, etc.) (Nazir et al., 2019; Lakra and Mishra, 2018). Application of potassium mobilizing bacteria (KMB) exhibiting different plant growth promoting (PGP) traits would not only deal with the nutrient deficiency but also improve crop yield and soil fertility. In view of this, the present work is designed to isolate potent KMBs from different agro climatic zones of Odisha, India, dynamics of soil potassium and validation of PGPR traits with its effect on the oil producing crop, sunflower.

\section{MATERIALS AND METHODS}

\subsection{COLLECTION OF SOIL SAMPLE}

Rhizospheric soil samples were collected aseptically from various crops at different agroclimatic locations of Bargarh, Kakatpur, Jharsuguda, Nimapara, ICAR-NRRI, Cuttack, Rourkela, Sonepur, Sambalpur, Sundergarh, Bhubaneswar and OUAT. Top layer of the soil (about $1 \mathrm{~cm}$ ) was removed and 3 samples of about $10 \mathrm{~g}$ of each were collected at the depth of $10-20 \mathrm{~cm}$, mixed thoroughly and aseptically put in polythene packets with proper labels.

\subsection{ISOLATION OF RHIZOBACTERIA}

Standard isolation method was followed taking specimens randomly, without any prior knowledge of the microbial composition at the source under investigation (Donaldio et al., 2002). The rhizospheric samples were processed in the laboratory and microorganisms were isolated in vitro in basal medium. Enumerations of heterotrophic bacteria were conducted through serial dilution method and spread plate technique. One g of soil sample was suspended in $10 \mathrm{ml}$ sterile distilled wa- 
ter, logarithmic dilutions were made upto $10^{-4}$ level and $100 \mu \mathrm{l}$ suspensions was spread on nutrient agar plate (NA). The plates were incubated at $37 \pm 1{ }^{\circ} \mathrm{C}$ for $24 \mathrm{~h}$. The CFUs of different morphology were then selected and sub cultured on NA slants, incubated for $24 \mathrm{~h}$ at $37 \pm 1{ }^{\circ} \mathrm{C}$ and the slants were numbered and preserved at $4{ }^{\circ} \mathrm{C}$. The slant cultures were periodically subculture and used for different experiments. The isolated bacteria were coded with number for further experiment.

\subsection{QUALITATIVE TEST FOR KMB}

The potassium mobilization test was done on $\mathrm{Al}$ exandrow's medium. Isolates were spot inoculated in agar plates and incubated for $72 \mathrm{~h}$ at $37^{\circ} \mathrm{C}$ (Zhang and Kong, 2014). A clear zone around the colony was taken as positive for potassium metabolism.

\subsection{VALIDATION OF PLANT GROWTH PRO- MOTING TRAITS(PGP)}

Plant growth promoting activities of bacteria were tested in vitro. The PGPR traits viz. IAA production, phosphate solubilization, ammonia production, nitrate reduction test, antibiosis and siderophore production were determined with following standard methods ( $\mathrm{Pa}$ hari and Mishra, 2017).

\subsubsection{IAA production}

The qualitative test for IAA was carried out following Bric et al. (1991). Rhizobacterial isolates were inoculated in $5 \mathrm{ml}$ peptone water amended with $0.1 \%$ tryptophan and incubated at $30^{\circ} \mathrm{C}$ for $48-72 \mathrm{~h}$ in dark. Salkowski reagent $\left(2 \% 0.5 \mathrm{M} \mathrm{FeCl}_{3}\right.$ in $35 \%$ (v/v) perchloric acid) was added in tubes and observed for pink colour development in the concerned tubes.

\subsubsection{Phosphatesolubilization}

The phosphate solubilization test was done on Pikovaskaya medium (Pikovaskaya, 1948). Agar plates were prepared and the isolates were spot inoculated on it and incubated for $5-6$ days $37^{\circ} \mathrm{C}$. A clear zone around the colony was taken as positive for phosphate solubilization.

\subsubsection{Ammonia production}

All the isolates were tested for qualitative production of ammonia. Peptone water was prepared by the method of Dye (1962). All the isolates were inoculated in $1 \%(\mathrm{v} / \mathrm{v})$ peptone water and incubated at $30^{\circ} \mathrm{C}$ for 3 days. After the incubation period, $1 \mathrm{ml}$ of Nessler's reagent was added into each of the tubes. The presence of faint yellow colour indicated small amount of ammonia production and deep yellow to deep reddish brown colour indicated maximum production of ammonia.

\subsubsection{Nitrate reduction test}

The ability of the microorganisms to reduce nitrate to nitrite is detected through the test (Knapp and Clark, 1984). All ten isolates were inoculated into nitrate broth, incubation at $30{ }^{\circ} \mathrm{C}$ for 96 hours. After inoculation sulphanillic acid and $\alpha$-naphthylamine mixture (1:1) was added. Appearance of deep pink colour indicated positive result.

\subsubsection{Antibiosis}

This test was carried out for isolates against the pathogenic fungi Fusarium sp. (Link, 1809) All screenings were carried out on PDA plates for fungal pathogens (Zhao et al., 2018). An actively growing fungal agar plug ( $3 \mathrm{~mm}$ diameter) was placed at centre of PDA plates. Bacterial isolates were inoculated and the plates were incubated for four days at $28{ }^{\circ} \mathrm{C}$.

\subsubsection{Siderophoreproduction}

Production of siderophore was assayed by growing them on Chrome azurol S (CAS) agar plates at $28 \pm$ $2{ }^{\circ} \mathrm{C}$ for 5 days incubation (Schwyn and Neilands, 1987). Appearance of yellow or brown zone around the colony indicated positive result for siderophore production.

\subsection{MORPHO-PHYSIOLOGICAL AND BIOCHEM- ICAL CHARACTERIZATION}

Six isolates showing more number of PGP traits were selected for further characterization and application. Gram's reaction was conducted on the isolated microorganisms to study their morphology. The organisms were taken and inoculated in freshly prepared and sterilized peptone water. A basic biochemical test that 
includes IMViC was performed following indole test, MR test, Voges-Proskauer test and citrate utilization test. In addition to this, manitol motility test, ONPG test and TSI test was also conducted (Pahari and Mishra, 2017).

\subsubsection{Enzymatic test}

Isolates were tested for oxidase, urease, catalase, starch hydrolysis, casein hydrolysis, esculin hydrolysis, DNAse, coagulase and decarboxylation test reaction (Gupta et al., 2000).

\subsubsection{Sugar utilization test (O-F Test)}

All isolates were inoculated in the freshly prepared carbohydrate fermentative O-F medium with the sugars. The sugars used for this test were xylose, sorbitol, cellobiose, salicin, raffinose and inositol. Colour change to yellow indicated positive results.

\subsection{GROWTH IN DIFFERENT PHYSICAL PA- RAMETERS}

Nutrient broth was used for this test. The $\mathrm{pH}$ was maintained to 5.6. The isolates were inoculated into it and incubated 24 hours at $37^{\circ} \mathrm{C}$. Growth in $7 \% \mathrm{NaCl}$ was done by adding $7 \% \mathrm{NaCl}$ to the medium and sterilized (Tank and Saraf, 2009). The isolates were inoculated and incubated for 24 hours at $37^{\circ} \mathrm{C}$. Growth of isolates at different temperature was also tested by inoculating the isolates in nutrient broth, which were further incubated at $10{ }^{\circ} \mathrm{C}, 45^{\circ} \mathrm{C}$ and $65^{\circ} \mathrm{C}$ for 24 hours (Getahun et al., 2020). The growth in medium indicated positive result.

\subsection{ANAEROBIC GROWTH}

Thioglycolate slant plus butt was prepared according to Chandler (2013). The isolates were inoculated into it by stabbing followed by streaking method. A sterile cotton plug was inserted into the tube followed by the addition of pyrogallol powder and $\mathrm{NaOH}$. Paraffin tape was wrapped around the tube and incubated at $37{ }^{\circ} \mathrm{C}$ for $72 \mathrm{~h}$ in an inverted manner. Growth in the medium indicated a positive result.

\subsection{ANTAGONISTIC EFFECT BETWEEN OR- GANISMS}

To determine negative interactions amongst the isolates in consortium application, inhibiting growth of each other was studied. The experiment was carried out on nutrient agar plates. One of organism was lawn cultured and five other organisms were inoculated on the wells made on the agar. Similar method was followed for all the selected isolates.

The plates were observed for the production of halo-zones around the wells which would a negative interaction between the test organisms.

\subsection{EVALUTION OF EFFECTIVE BACTERIAL ISOLATES ON SEED GERMINATION}

The potent bacterial isolates were further tried with sunflower seeds for determination of effect on germination under laboratory condition.

\subsection{POT CULTURE METHOD}

Sunflower seeds were sown in different pots based on randomized block design. The inoculums were centrifuged and added in single and consortium to the pots. Nomenclature of the organisms was done as T1 to T6, consortium was T7 and control was C.

\subsection{RESIDUAL SOIL POTASSIUM}

The available potassium in the soil was estimated by following the ammonium acetate extract protocol of Malathi and Stalin (2018). The estimation of potassium in soil was done on 10 to 30 days at an interval of 10 days post addition of inoculums. Soil and ammonium acetate were mixed in the ratio of $1: 10$. It was incubated in the shaker incubator for 30 minutes at 90 RPM and 25 degree Celsius. After digestion, the solution was filtered out and further analysis was carried out in ICP-OES, from which the available potassium was estimated. 


\section{RESULTS}

\subsection{ISOLATION OF POTASH MOBILIZING BAC- TERIA FROM THE RHIZOPHERIC SOIL}

A total of 84 morphologically distinct colonies isolated from different rhizospheric soil sample and were screened for potassium mobilization using Alexandrow's medium agar plates. KMB positive bacteria were observed by the formation of clear zone in the agar plates. Out of the 84 isolated bacteria, a total of 30 potent KMBs were positive (Table 1; Fig. 1).

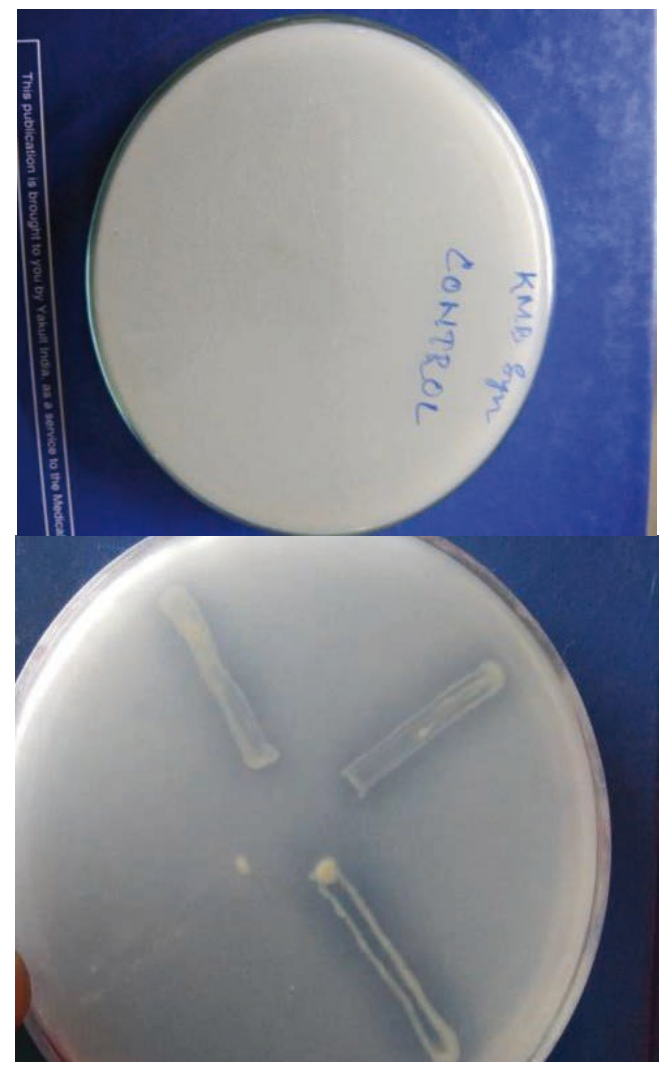

Fig. 1: Potassium solubilisation by the isolates

\subsection{PLANT GROWTH PROMOTING TRAITS OF THE POTENT KMB ISOLATES}

The plant growth promoting traits like IAA production, phosphate solubilization and ammonia production are presented in Table 1, Figure 2. Nitrate reduction test, antibiosis and siderophore production exhibited by the isolates along with potassium mobilization. These traits are effective for enhancement in growth and productivity of the crop. The isolates showing maximum plant growth promoting traits in addition to potassium mobilisation were selected from the 30 test organisms. The highest
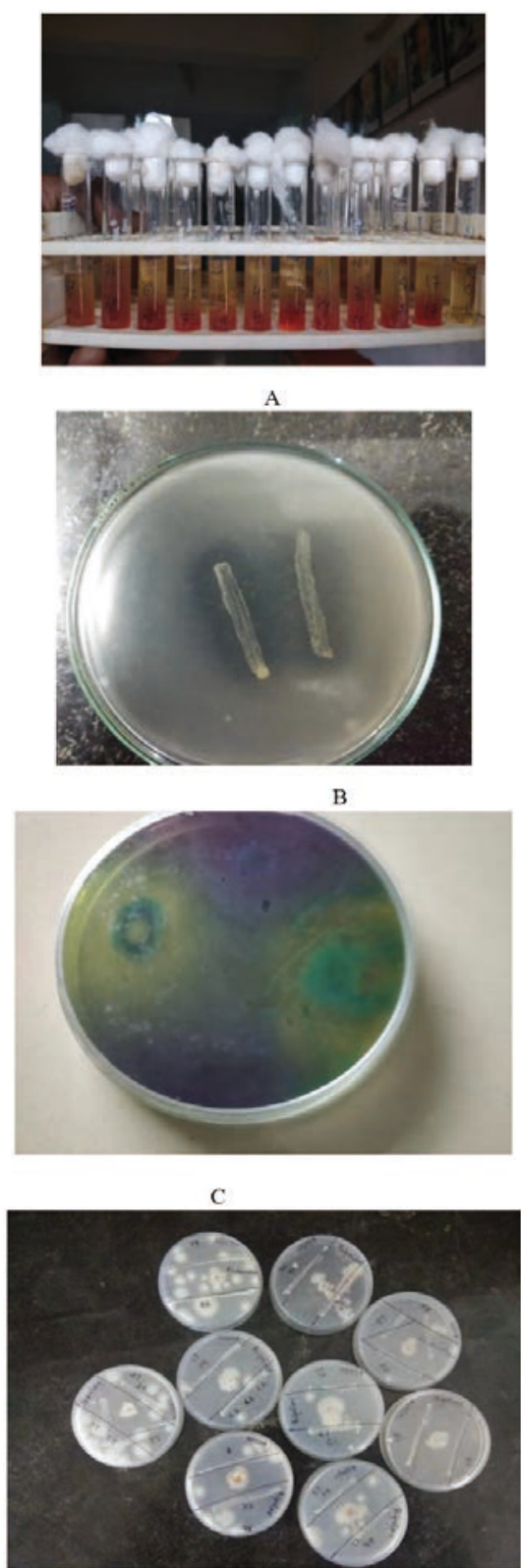

D

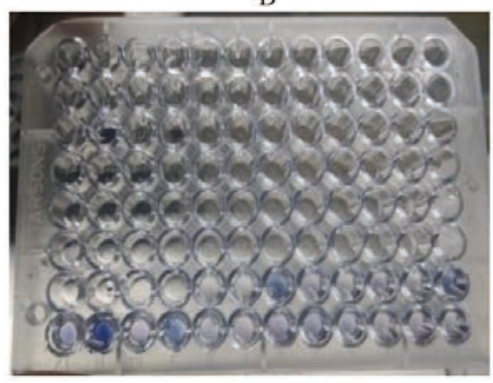

E

Fig. 2: Plant growth promoting traits exhibited by the isolates (A: Indole acetic acid production; B-Phosphate solubilizing bacteria test; C-Siderophore production;

D-Antibiosis; E-Nitrate reduction test.) 


\section{A. PANDA et al.}

Table 1: KMB and plant growth promoting characteristics of the potential isolates

\begin{tabular}{|c|c|c|c|c|c|c|c|c|}
\hline Isolates & KMB & PSB & IAA & SIDO & AMM & NIT & ANTI & TOTAL \\
\hline 26 & + & - & - & - & - & + & + & 4 \\
\hline 27 & + & + & - & + & - & + & + & 6 \\
\hline 33 & + & - & - & + & - & - & - & 3 \\
\hline 39 & + & - & + & + & - & - & - & 4 \\
\hline 43 & + & + & - & + & - & - & - & 4 \\
\hline 44 & + & - & - & + & - & - & - & 3 \\
\hline 46 & + & + & + & + & - & + & + & 7 \\
\hline 47 & + & - & - & + & - & - & + & 4 \\
\hline 54 & - & + & - & + & - & - & + & 4 \\
\hline 55 & + & - & - & + & - & - & - & 3 \\
\hline 56 & + & + & + & + & + & + & + & 8 \\
\hline 58 & + & - & - & + & - & - & - & 3 \\
\hline 59 & + & - & - & - & - & - & - & 2 \\
\hline 61 & + & + & + & + & - & - & - & 5 \\
\hline 62 & + & + & - & + & - & - & + & 5 \\
\hline 63 & + & - & + & - & - & - & - & 3 \\
\hline 69 & + & - & - & + & - & - & - & 3 \\
\hline 72 & + & - & - & + & - & + & + & 5 \\
\hline 74 & + & + & - & + & - & - & - & 4 \\
\hline 76 & - & - & + & - & + & - & - & 3 \\
\hline 77 & + & + & + & + & + & + & + & 8 \\
\hline 78 & + & + & + & + & + & + & + & 8 \\
\hline 79 & + & - & - & + & - & - & + & 4 \\
\hline 81 & + & + & - & + & - & - & - & 4 \\
\hline 83 & + & + & - & + & + & - & - & 5 \\
\hline 84 & + & + & + & - & + & + & + & 7 \\
\hline
\end{tabular}

+:Positive for the trait, -: negative for the trait; KMB: Potassium mobilizing bacteria, PSB: Phosphate Solubilizing bacteria, IAA: Indoleacetic acid, SIDO: Siderophore, AMM: Ammonification, NIT: Nitrification, ANTI: Antibiosis

Table 2: Physical-chemical parameters of soil samples having potash mobilizing isolates

\begin{tabular}{lllll}
\hline Isolates & Sampling Site & $\mathrm{pH}(1: 2, \mathrm{w} / \mathrm{v})$ & $\begin{array}{l}\text { Soil Organic Carbon } \\
(\mathrm{SOC})\left(\mathrm{g} \mathrm{kg}^{-1}\right)\end{array}$ & $\begin{array}{l}\text { Electrical conductivity } \\
\left.(\mathrm{EC})(\mathrm{dS} \mathrm{m})^{-1}\right)\end{array}$ \\
\hline 27 & Nimapada & 6.38 & 7.3 & 0.093 \\
46 & Rourkela & 6.71 & 8.25 & 0.038 \\
56 & Sonepur & 8.1 & 9.81 & 0.167 \\
$77,78,84$ & OUAT Field & 6.52 & 6.9 & 0.088 \\
\hline
\end{tabular}


eight number of PGP traits were depicted by isolate number 56,77 and 78 . Isolate number 46 and 84 were positive for seven traits. Isolate number 27 exhibited positive results for six PGP traits. Soil from four agroclimatic zones having bacteria with potash mobilizing and plant growth promoting properties were analysed (Table. 2 ) These six isolates were then used for further biochemical characterization and application in crop.

\subsection{MORPHO-PHYSIOLOGICAL AND BIOCHEM- ICAL CHARACTERIZATION}

From the colony morphology and gram's reaction of all the six isolates, it was observed that the colonies were small, smooth, irregular and raised with Gram positive rods and cocci (Table3; Fig. 3). Furthermore basic biochemical tests revealed, all the six isolates were indole negative, Vokes Proskeur positive and besides 44 and 77 , all the isolates were positive for citrate utilization. Other than 78, mannitol motility was positive in other isolates. The isolates had positive growth at $45^{\circ} \mathrm{C}$ and negative growth at $65{ }^{\circ} \mathrm{C}$ and $10{ }^{\circ} \mathrm{C}$. Growth at $\mathrm{pH}$ 5.7 and anaerobic medium was found to be positive in all. All the isolates were positive for esculin hydrolysis, catalase, oxidase, urease, arginine dehydrolase, ONPG and negative for starch \& casein hydrolysis, DNAse, ornithine decarboxylase and coagulase. Each of the isolates except 77, showed negative result in nitrate reductase and in case of lysine decarboxylase 27, 46, 56 were negative and $77,78,84$ were positive (Table. 4). Moreover all the isolates depicted positive result in triple sugar iron test (Table 5). Gas production was observed in all but 77 and 84 . As for sugar utilization, all the isolates could utilize cellobiose, raffinose, sorbitol and xylose (Table 6). En route to further experimenta- tion, nomenclature was done as; 27-T1, 46-T2, 56-T3, 77-T4, 78-T5, 84-T6, the consortium of all the isolates was $\mathrm{T} 7$ and control as $\mathrm{C}$.
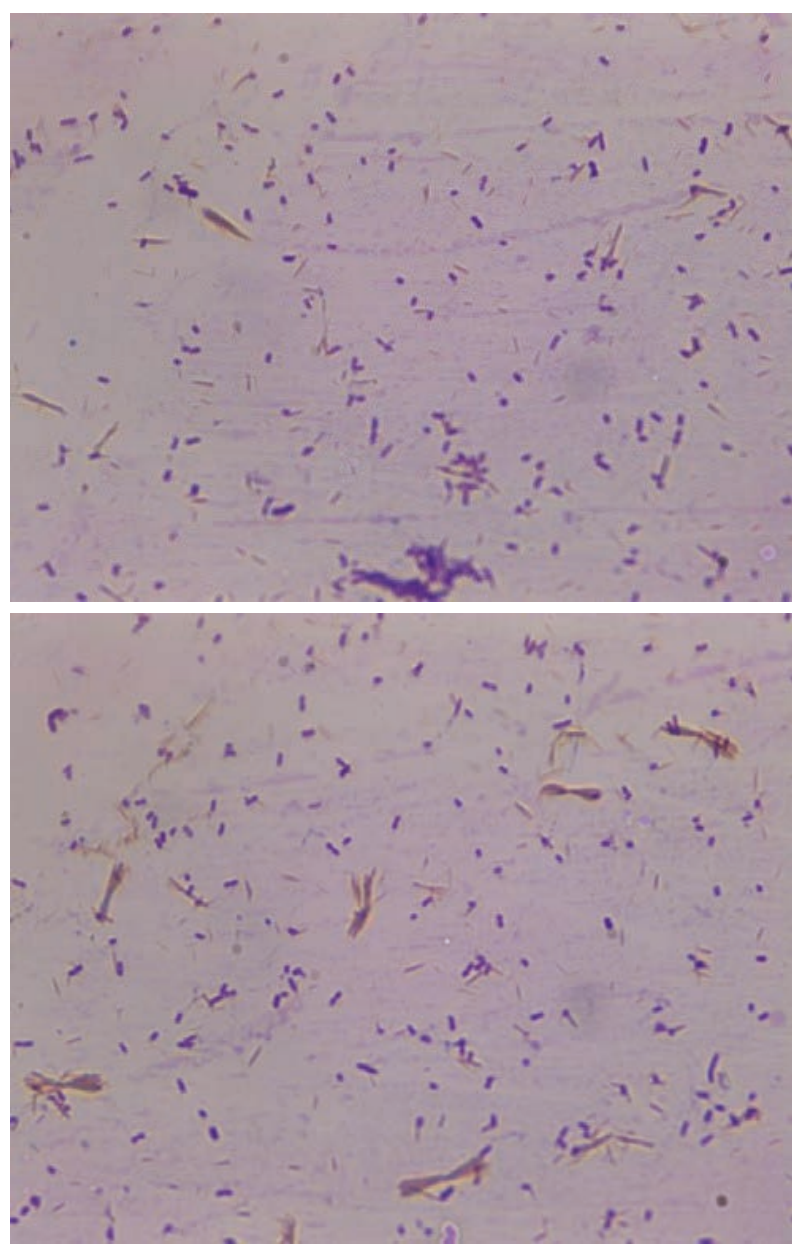

Fig. 3: Gram’s staining

Table 3: Colony morphology and Gram's variability of the isolates

\begin{tabular}{|c|c|c|c|c|c|c|}
\hline characteristics & 27 & 46 & 56 & 77 & 78 & 84 \\
\hline Shape & Circular & Irregular & Irregular & Irregular & Irregular & Irregular \\
\hline Elevation & Raised & Crateriform & Convex & Raised & Umbonate & Raised \\
\hline Margin & Entire & Curled & Undulate & Undulate & Lobate & Undulate \\
\hline Size & Small & Large & Small & Medium & Small & Medium \\
\hline Surface & Smooth & Rough & Rough & Smooth & Smooth & Smooth \\
\hline Colour & White & White & White & White & White & white \\
\hline Opacity & Opaque & Opaque & Opaque & Opaque & Translucent & opaque \\
\hline Gram & Gram +ve & Gram & Gram+ve & Gram +ve & Gram & Gram+ve \\
\hline staining & Rod & +verod & rod & rod & +ve cocci & cocci \\
\hline
\end{tabular}


Table 4: Biochemical characterization of the isolates

\begin{tabular}{|c|c|c|c|c|c|c|c|}
\hline SINo & Biochemical test & 27 & 46 & 56 & 77 & 78 & 84 \\
\hline 1 & Indole & - & - & - & - & - & - \\
\hline 2 & Vogeus- Proskaur & + & + & + & + & + & + \\
\hline 3 & Citrate utilization & + & - & + & - & + & + \\
\hline 4 & Mannitol motility test & + & + & + & + & - & + \\
\hline 5 & Growth at $45^{\circ} \mathrm{C}$ & + & + & + & + & + & + \\
\hline 6 & Growth at $65^{\circ} \mathrm{C}$ & - & - & - & - & - & - \\
\hline 7 & Growth at $10^{\circ} \mathrm{C}$ & - & - & - & - & - & - \\
\hline 8 & Growth at pH5.7 & + & + & + & + & + & + \\
\hline 9 & Anaerobic Growth & + & + & + & + & + & + \\
\hline 10 & Starch hydrolysis & - & - & - & - & - & - \\
\hline 11 & Casein hydrolysis & - & - & - & - & - & - \\
\hline 12 & Esculin hydrolysis & + & + & + & + & + & + \\
\hline 13 & Catalase & + & + & + & + & + & + \\
\hline 14 & Oxidase & + & + & + & + & + & + \\
\hline 15 & Urease & + & + & + & + & + & + \\
\hline 16 & DNase & - & - & - & - & - & - \\
\hline 17 & Arginine dihydrolase & + & + & + & + & + & + \\
\hline 18 & Lysine decarboxylase & - & - & - & + & + & + \\
\hline 19 & Ornithine decarboxylase & - & - & - & - & - & - \\
\hline 20 & Nitrate reductase & - & - & - & + & - & - \\
\hline 21 & Coagulase & - & - & - & - & - & - \\
\hline 22 & ONPG & + & + & + & + & + & + \\
\hline
\end{tabular}

Table 5: Triple Sugar Iron Test

\begin{tabular}{lllll}
\hline Isolate no. & Alkaline slant & Acidic butt & H2S Production & Gas Production \\
\hline 27 & + & + & + & + \\
46 & + & + & + & + \\
56 & + & + & + & + \\
77 & + & + & + & + \\
78 & + & + & + & + \\
84 & + & + & + & - \\
\hline
\end{tabular}

Table 6: Sugar Utilization

\begin{tabular}{|c|c|c|c|c|c|c|c|c|c|c|c|c|}
\hline \multirow[t]{2}{*}{ Isolate no. } & \multicolumn{2}{|c|}{ Cellobiose } & \multicolumn{2}{|c|}{ Inositol } & \multicolumn{2}{|c|}{ Raffinose } & \multicolumn{2}{|c|}{ Salicin } & \multicolumn{2}{|c|}{ Sorbitol } & \multicolumn{2}{|c|}{ Xylose } \\
\hline & $\mathrm{O}$ & $\mathrm{F}$ & $\mathrm{O}$ & $\mathrm{F}$ & $\mathrm{O}$ & $\mathrm{F}$ & $\mathrm{O}$ & $\mathrm{F}$ & $\mathrm{O}$ & $\mathrm{F}$ & $\mathrm{O}$ & $\mathrm{F}$ \\
\hline 27 & + & + & - & + & + & + & - & + & + & + & + & + \\
\hline 46 & + & + & - & - & + & + & - & - & + & + & + & + \\
\hline 56 & + & + & - & - & + & + & - & - & + & + & + & + \\
\hline 77 & + & + & - & - & + & + & - & + & + & + & + & + \\
\hline 78 & + & + & - & + & + & + & + & + & + & + & + & + \\
\hline 84 & + & + & - & + & + & + & + & + & + & + & + & + \\
\hline
\end{tabular}




\subsection{INTERACTION BETWEEN ISOLATES}

No inhibition zone was reported around the wells indicating that the organisms were not antagonistic to each other and can be used in a consortium (Fig. 4).

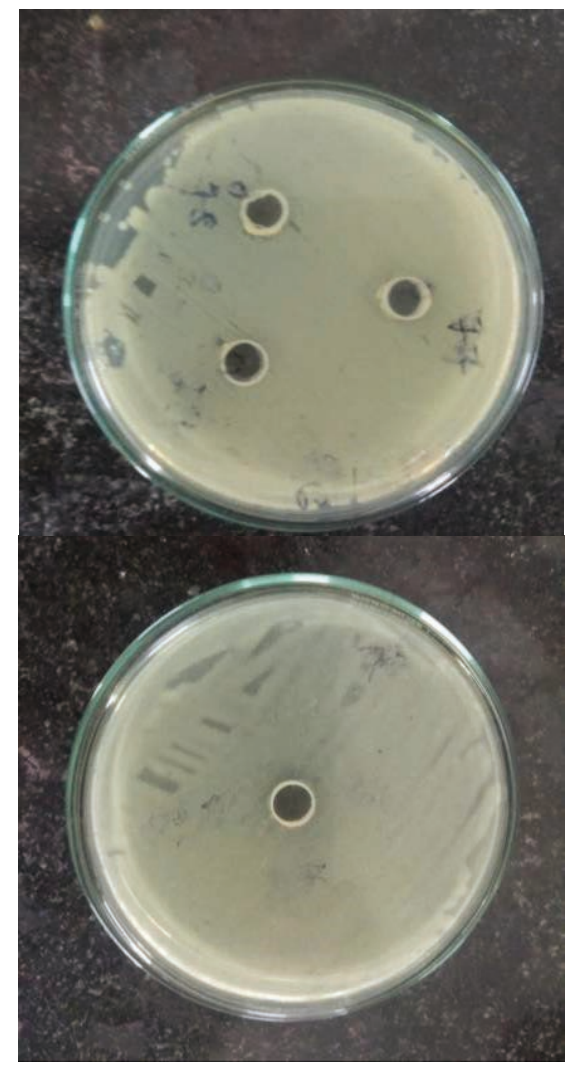

Fig. 4: Interaction between the isolates

\subsection{EFFECT OF THE ISOLATES ON THE GERMI- NATION OF SUNFLOWER SEEDS}

Seed germination was studied by using germination paper following the roll towel method under laboratory conditions. It was found that in all the isolates except T4, the percentage of germination was significantly higher (40-50 \%) as compared to the control (Table.7; Fig. 5).

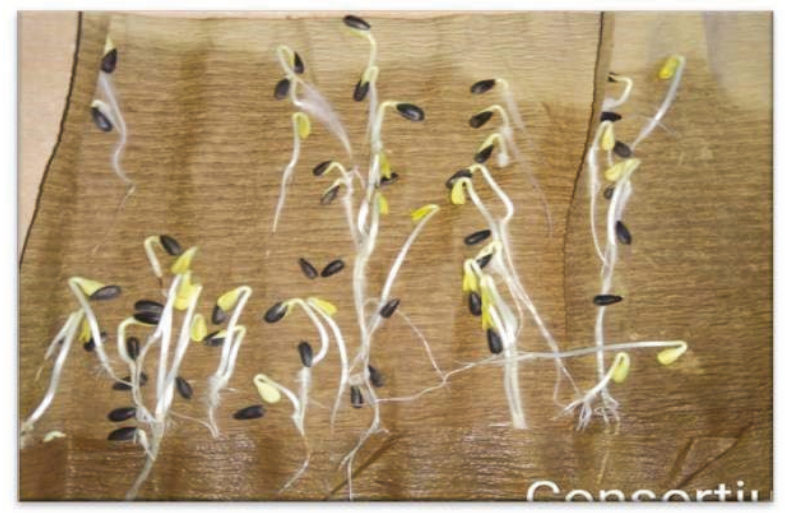

Fig. 5: Seed germination of sunflower by the isolates

\subsection{EFFECT OF THE ISOLATES ON SUNFLOWER CROPS IN POT CULTURE METHOD}

The shoot length of sunflower increased with inoculation of the organisms and in consortia (Fig. 6(a)). The percentage of increase ranged between $54.2 \%$ with the organism T6 to $124.1 \%$ with T1 in 30days over that of the 10 days. Maximum increase of $144 \%$ in shoot length with consortium (T7) was reported. The control

Table 7: Effect of the isolates on germination of Sunflower seed

\begin{tabular}{lllllllll}
\hline Isolate & $\mathrm{C}$ & $\mathrm{T} 1$ & $\mathrm{~T} 2$ & $\mathrm{~T} 3$ & $\mathrm{~T} 4$ & $\mathrm{~T} 5$ & $\mathrm{~T} 6$ & T7 \\
\hline Germination percentage (\%) & 52 & 98 & 92 & 92 & 40 & 100 & 95 & 98 \\
\hline
\end{tabular}

Table 8: Changes in shoot length of sunflower $(\mathrm{cm})$ with application of the isolates and in consortia

\begin{tabular}{llll}
\hline Isolate & 10 days & 20 days & 30 days \\
\hline T1 & 8.7 & $11.8(+35.63 \%)$ & $19.5(+124.1 \%)$ \\
T2 & 12.8 & $16.5(+22.42 \%)$ & $25(+95.312 \%)$ \\
T3 & 14.36 & $15.7(+9.33 \%)$ & $26.1(+81.75 \%)$ \\
T4 & 15.96 & $17.33(+8.58 \%)$ & $25.6(+60.40 \%)$ \\
T5 & 13.9 & $15.4(+10.79 \%)$ & $24.5(+76.25 \%)$ \\
T6 & 15.43 & $17.76(+15.1 \%)$ & $23.8(+54.24 \%)$ \\
T7 & 10 & $11.8(+18 \%)$ & $24.4(+144 \%)$ \\
C & 12.63 & $15.9(+25.89 \%)$ & $20.23(+60.17 \%)$ \\
\hline
\end{tabular}


set $(C)$ there was an increase of $60.17 \%$ in 30 days over that of the 10 days (Table 8; Fig. 6(b)).

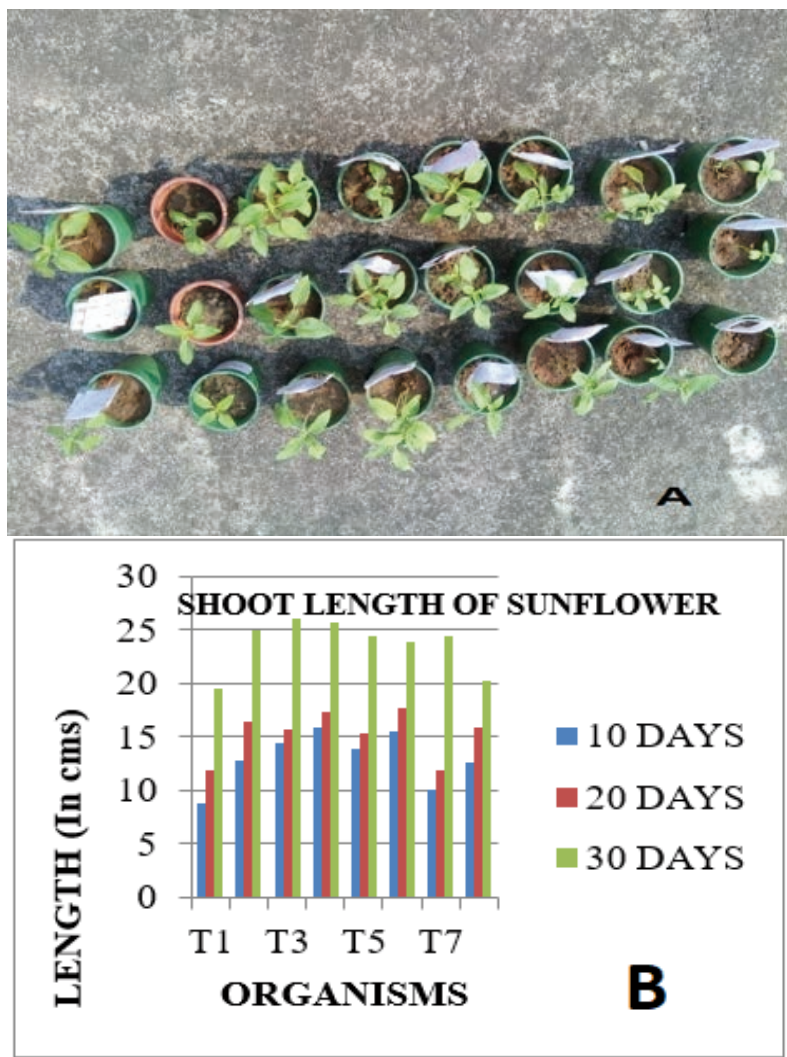

Fig. 6: (A) Sunflower plants in pot culture method; (B) Shoot length of sunflower (graph)

\subsection{AVAILABLE POTASSIUM IN SOIL}

The amount of soil available potassium decreased with increase in time from 10 days to 30 days (Table 9; Fig. 7). It decreased $2.85 \%$ with isolate T1, $5.26 \%$ with T2, $20.04 \%$ with isolate T3, $19.62 \%$, with T4, $10.45 \%$ with T5 and $9.94 \%$, decrease of with isolate T6. Per- cent decrease in soil potassium content was maximum $26.31 \%$ with consortium (T7). In case of control, an increase of $7.61 \%$ available soil potassium content was reported.The decrease in soil potassium content with time was statistically significant $(p \leq 0.5)$.

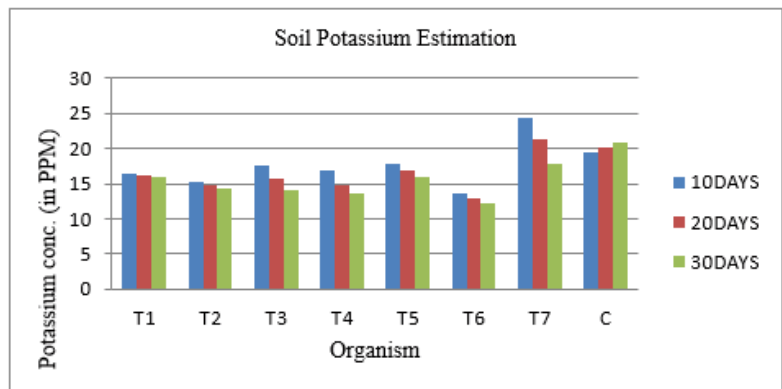

Fig.7: Soil potassium estimation in sunflower

\section{DISCUSSION}

\subsection{ISOLATION OF POTASH MOBILIZING BAC- TERIA}

In view of the adverse effects of chemical fertilizers and agrochemical application in crop fields, organic farming is advocated in Green Revolution-II. Soil is a rich source of organic matter, mostly released through root exudates. Forty percent of the photosynthate, released through the root, provides an ideal environment for the microbes to inhabit in the rhizospheric region (Bramhaprakash et al., 2017). These organic matters also contain many macro and micro nutrient in combined form which is unavailable to plants for its growth and metabolism. Soil microbes including PGPR have the potential to solubilise these elements including potassium through various mechanisms and make it available to plants (Pradhan and Mishra, 2015; Dhaked et al., 2017).Archana et al. (2013) isolated 4 potent KMBs from crop field soil. In the present investigation, 30 out

Table 9: Soil potassium content (ppm) with application of the potential organisms and in consortia

\begin{tabular}{llll}
\hline Isolate & 10 days & 20 days & 30 days \\
\hline T1 & 16.46 & $16.25(-1.21 \%)$ & $15.99(-2.85 \%)$ \\
T2 & 15.2 & $14.71(-3.22 \%)$ & $14.4(-5.26 \%)$ \\
T3 & 17.56 & $15.792(-10.06 \%)$ & $14.04(-20.04 \%)$ \\
T4 & 16.97 & $14.82(-12.66 \%)$ & $13.64(-19.62 \%)$ \\
T5 & 17.89 & $16.98(-5.08 \%)$ & $16.02(-10.45 \%)$ \\
T6 & 13.58 & $12.89(-5.081 \%)$ & $12.23(-9.94 \%)$ \\
T7 & 24.28 & $21.33(-12.14 \%)$ & $17.89(-26.31 \%)$ \\
C & 19.43 & $20.11(+3.4 \%)$ & $20.91(+7.61 \%)$ \\
\hline
\end{tabular}


of 84 organisms isolated from the soil samples of various agroclimatic regions of Odisha exhibited potassium mobilization.

\subsection{PLANT GROWTH PROMOTING TRAITS OF THE KMB ISOLATES}

The 30 potential isolates with KMB potential exhibited PGP traits like IAA production, phosphate solubilization, ammonia production, nitrate reduction, antibiosis and siderophore production. Dinesh et al. (2018) reported that soil bacteria and isolates from industrial effluent (Lakra et al., 2019) exhibited various PGP traits as reported in the present investigation. Pahari and Mishra (2017) isolated siderophore producing bacteria from different regions of Odisha, showing various PGP traits like IAA production, phosphate solubilization, ammonia production, nitrate reduction, antibiosis. On application in crop fields, these PGP microbes increased productivity of rice, mungbean and ground nut (Pradhan et al., 2016). In the present investigation, 6 out of 30 isolates exhibited maximum number of PGP traits; 56, 77, 78 showed eight PGP traits, 46 and 84 were positive for seven and 27 for six PGP traits.

\subsection{MORPHO-PHYSIOLOGICAL AND BIOCHEM- ICAL CHARACTERIZATION OF THE POTEN- TIAL ISOLATES}

The colony morphology, Gram's variability and biochemical characteristics of the six isolates carried out in accordance with ABIS software for bacterial identification showed the organisms to be species of Bacillus and Coccus which corroborates with the findings of Pahari et al. (2017) who isolated species of Bacillus from the coastal soil samples and halotolerant Enterobacteriaceae, Clostridium (Prazmowski, 1880) and Corynebacterium spp. (Lehmann \& Neumann, 1896) from soil confirmed after biochemical characterization followed by using ABIS software (Rahman et al., 2017).

\subsection{EFFECT OF THE ISOLATES ON SUNFLOWER IN POT CULTURE METHOD}

A significant increase in shoot length of the sunflower was reported with application of the organisms in isolation and in consortia as compared to the control. Concomitant to this, Pradhan and Mishra (2015) reported a significant increase in shoot length of rice, mung bean and groundnut with the application of rhizospheric bacteria. The potential six isolates exhibiting many PGP traits are effective in increasing the growth of crop with enhanced nutrients availability and plant growth promoting traits. Similar increase in shoot length of brinjal, tomato and okra was reported by $\mathrm{Pa}$ hari and Mishra (2017) with the application of siderophore producing bacteria isolated from soil of Ganjam and Khurda district of Odisha with reduced application of chemical fertilizer.

\subsection{MOBILIZATION OF SOIL POTASSIUM}

Park et al. (2003) reported that bacterial inoculation could improve phosphorus and potassium availability in the soils by producing organic acid like oxalic acid, tartaric acids and also due to the production of capsular polysaccharides which helps in dissolution of minerals to release potassium (Sheng and He, 2006; Prajapati et al., 2013) in addition to other growth stimulating chemicals facilitating plant mineral uptake. A significant decrease in sunflower soil potassium content, quantitatively analysed through ICP-OES with application of KMBs could be due to its accumulation of potassium by the plant. Bhattacharyya et al. (2016) reported increase in potash content following application of KMBs to tea soil. The decrease in $\mathrm{K}$ content in this finding is due to accumulation of solubilized potassium by sunflower plants (Dash, 2019).

It is evident from the present investigation that the six isolates have a potential for potassium mobilization with various PGP traits which increased growth of the oil seed crop sunflower.

\section{CONCLUSION}

Six of the 84 isolates mobilized $\mathrm{K}$ in addition to different PGP traits. The 6 isolates along with the consortium when applied on sunflower seeds in pot culture showed increased absorption of potassium in the soil. Among the 6 bacterial isolates, T7 showed $144 \%$ increase in shoot length in sunflower plant and $26.31 \%$ decrease in available soil potassium suggests absorption of potassium by the crop plant. The six organisms in consortia, reported better growth of the crop. It is evident that they can supplement potassium to the plants by solubilizing complex forms. Moreover, the organism showing higher PGP traits along with the potassium solubilizing have a greater agricultural and environmental significance and can be a replacement for chemical fertilizers. 


\section{ACKNOWLEDGEMENT}

Financial assistance by Department of Science and Technology (DST), Government of India through DSTINSPIRE Fellowship is duly acknowledged.

\section{REFERENCES}

Archana, D., Nandish, M., Savalagi, V., Alagawadi, A. (2013). Characterization of potassium solubilizing bacteria (KSB) from rhizosphere soil. BIOINFOLET-A Quarterly Journal of Life Science, 10, 248-257. https://doi.org/10.9734/JALSI/2017/36848

Ash, C., Priest, F.G., Collins, M.D. (1994). Paenibacillus gen. nov. and Paenibacillus polymyxa comb. Nov. In Validation of the publication of new names and new combinations previously effectively published outside the IJSB, List no. 51. International Journal of Systemic Bacteriology, 44, 852. https://doi.org/10.1099/00207713-44-4-852

Avakyan, Z.A., Pivovarova, T.A., Karavaiko, G.I. (1986). Characteristics of a new Bacillus mucilaginosus species. Mikrobiologiia, 55, 477-482.

Bhattacharyya, P.N. \& Jha, D.K. (2012).Plant growth-promoting rhizobacteria (PGPR): emergence in agriculture. World Journal of Microbiology and Biotechnology, 28(4), 1327-50. https://doi.org/10.1007/s11274-011-0979-9

Bhattacharrya, P., Dutta, P., Madhab, M., Phukan, I.K. (2016). Isolation of potash mobilizing microorganisms in tea soil and evaluation of their efficiency in potash nutrition in tea: a novel approach. Two and a Bud, 63, 8-12.

Bric, J., Bostoc, R., Silverstone, S. (1991). Rapid in situ assay for indole acetic acid production by bacteria immobilized on a nitrocellulose membrane. Applied Environmental Microbiology, 57, 535-538. https://doi.org/10.1128/ aem.57.2.535-538.1991

Blake, L., Mercik, S., Koerschens, M., Goulding, S., Stempen, S., Weigel, A., Poulton, P.R., Powlson, D.S. (1999). Potassium content in soil, uptake in plants and the potassium balance in three European long-term field experiments. Plant and Soil, 216, 1-14. https://doi.org/10.1023/A:1004730023746

Brahmaprakash, G.P., Sahu, P., Lavanya, G., Nair, S., Gangaraddi, V., Gupta, A., (2017). Microbial functions of the rhizosphere. In D. Singh, H. Singh, R. Prabha (eds.) Plant-Microbe Interactions in Agro-Ecological Perspectives. (pp. 177-210), Springer, Singapore. https://doi.org/10.1007/978-981-105813-4_10

Chandler, L. (2013). Challenges in clinical microbiology testing. In: Dasgupta, A., Sepulveda, J.L. (eds.) Accurate Results in Clinical Laboratory, Elsevier, pp-315-326. https://doi. org/10.1016/B978-0-12-415783-5.00020-7

Dash, A. (2019). Biofortification of zinc \& potassium by plant growth promoting rhizobacteria on oilseed crops with special reference to growth performance. M.Sc. Thesis, Odisha University of Agriculture and Technology, BBSR, Odisha, India.

Dhaked, B.S., Triveni, S., Reddy, R.S., Padmaja, G. (2017). Isolation and screening of potassium and zinc solubiliz- ing bacteria from different rhizosphere soil. International Journal of Current Microbiology and Applied Sciences, 6(8), 1271-1281. https://doi.org/10.20546/ijcmas.2017.608.154

Dinesh,R.,Srinivasan,V.,Hamza,S., Sarathambal, C., Gowda, S.J., Ganeshamurthy, A, Gupta, S.B., Nair, V., Subila, K., Lijina, A., Divya, V.C. (2018). Isolation andcharacterization of potential zinc solubilizing bacteria from soil and its effect on soil $\mathrm{Zn}$ release rates, soil available $\mathrm{Zn}$ and plant $\mathrm{Zn}$ content. Geoderma, 321, 173-186. https://doi.org/10.1016/j.geoderma.2018.02.013

Donaldio, S., Carrano, L., Brandi, L., et al. (2002). Targets and assays for discovering novel antibacterial agents. Journal of Biotechnology, 99, 175-185. https://doi.org/10.1016/ S0168-1656(02)00208-0

Dye, D.W. (1962). The inadequacy of the usual determinative tests for identification of Xanthomonas spp. New Zealand Journal of Science, 5, 393-416.

Malathi, P. \& Stalin, P. (2018). Evaluation of AB-DTPA extractant for multinutrients extraction in soils. International Journal of Current Microbiology and Applied Sciences, 7(3), https://doi.org/10.20546/ijcmas.2018.703.141

Getahun, A., Muleta, D., Aseefa, F., Kiros, S. (2020). Plant growth promoting rhizobacteria isolated from degraded habitat enhance drought tolerance of Acacia (Acacia abyssinica Hochst. ex Benth.) seedlings. International Journal of Microbiology. ID 8897998. https://doi. org/10.1155/2020/8897998

Gupta, A., Gopal, M., Tilak, K.V. (2000). Mechanism of plant growth promotion by rhizobacteria. Indian Journal of Experimental Biology, 38, 856-862.

Gurav, P.P., Choudhari, P.L., Srivastava, S. (2019). Role of clay minerals in potassium availability of black soils in India. Harit Dhara 2(1): Jan-June. Web link: http://iiss.nic.in/ eMagazine/v2i1/10.pdf

Jena, D., Pal, A.K., Rout, K.K. (2009). Potassium management for crops in soils of Orissa. Proceedings IPI-OUAT-IPNI International Symposium. Pp: 417-435.

Jordan, E.O. (1890). A report on certain species of bacteria observed in sewage. In Sedgewick, A report of biological work of the Lawrence experiment station, including an account of methods employed and results obtained in the microscopical and bacteriological investigation of sewage and water. Report on water supply and sewage, part 2. (pp. 821-844). Massachusetts State Board of Health, Boston.

Knapp, J.S. \& Clark, V.L. (1984). Anaerobic growth of Neisseria gonorrhoeae coupled to nitrite reduction. Infection and Immunity, 46, 176-181. https://doi.org/10.1128/iai.46.1.176181.1984

Lakra, P. \& Mishra, B.B. (2018). Plant growth promoting traits exhibited $\mathrm{b}$ metal tolerant bacterial isolates of industrial effluent. International Journal of Current Microbiology and Applied Science, 7(5), 3458-3471. https://doi.org/10.20546/ ijcmas.2018.705.400

Lakra, P., Pahari, A., Mishra, B.B. (2019). Biocontrol activity of metal tolerant plant growth promoting bacteria isolated from industrial effluent. Journal of Pharmacognosy and Phytochemistry, 8(6), 1617-1620.

Lehmann, K.B. \& Neumann, R. (1896). Atlas und Grundriss der Bakteriologie und Lehrbuch der speziellen bakteriologischen 
Diagnostik (Atlas and outline of bacteriology and textbook of special bacteriological diagnostics). First edition, Munchen:J.F. Lehmann.

Link, J.H.F. (1809). Observationes in ordines plantarum naturals. Dissertation I. Magazin der Gesellschaft Naturforschenden Freunde Berlin (in Latin), 3(1), 10.

Mishra, S.K. \& Mishra, P. (2016). Do adverse ecological consequences cause resistance against land acquisition? The experience of mining regions in Odisha, India. The Extractive Industries and Society, 4(2017), 140-150. https:// doi.org/10.1016/j.exis.2016.11.004

Morgan, J.B. \& Connolly, E.L. (2013). Plant-soil interactions: Nutrient uptake. Nature Education Knowledge, 4(8), 2.

Naidu, L.G.K., Ramamurthy, V., Sidhu, G.S., Sarkar, D. (2011). Emerging deficiency of potassium in soils and crops of India. Karnataka Journal of Agricultural Sciences, 24(1), 1219.

Nayak, S., Dash, B., Mishra, S., Mishra, B.B. (2020). Chitinase producing soil bacteria: Prospects and applications. Frontiers in Soil and Environmental Microbiology, 289-298. https://doi.org/10.1201/9780429485794-30

Nazir, N., Kamili, A., Shah, D. (2019). Mechanism of plant growth promoting rhizobacteria (PGPR) in enhancing plant growth - A Review. International Journal of Management, Technology and Engineering, 8(7), 709-721.

Pahari, A., Pradhan, A., Priyadarshini, S., Nayak, S., Mishra, B.B. (2017). Isolation and characterization of plant growth promoting rhizobacteria from coastal region and their effect on different vegetables. International Journal of Science, Environment and Technology, 6, 3002-3010.

Pahari, A. \& Mishra, B.B. (2017). Antibiosis of siderophore producing bacterial isolates against phytopathogens and their effect on growth of okra. International Journal of Current Microbiology and Applied Sciences, 6(8), 1925-1929. https://doi.org/10.20546/ijcmas.2017.608.227

Park, M., Singvilay,O., Seok, Y., Chung, J., Ahn, K., Sa, T. (2003). Effect of phosphate solubilising fungi on $\mathrm{P}$ uptake and growth to tobacco in rock phosphate applied soil. Korean Journal of Soil Science and Fertilizers, 36, 233-238.

Perez-Lucas, G., Nuria, V., Atik, A.E., Navarro, S. (2018). Environmental risk of groundwater pollution by pesticide leaching through the soil profile, pesticide-use and misuse and their impact in the environment, In M. Larramendy \& S. Soloneski, (eds), IntechOpen, https://doi.org/10.5772/ intechopen.82418

Peters, J. (2011). Average soil test phosphorous and potassium levels decline in Wisconsin. Department of soil science, Integrated pest and crop management. Web link: https:// ipcm.wisc.edu/blog/2011/01/average-soil-test-phosphorus-and-potassium-levels-decline-in-wisconsin/

Pikovskaya, R.I. (1948). Mobilization of phosphorus in soil in connection with the vital activity of some microbial pecies. Mikrobiologiya, 17, 362-370.

Pradhan, A. \& Mishra, B.B. (2015). Effect of plant growth promoting rhizobacteria on germination and growth of rice (Oryza sativa L.). The Ecoscan, 9(1 \& 2), 213-216.

Pradhan, A., Mohapatra, S., Samantaray, D., Mishra, B.B. (2016). A note on agricultural importance of PHAs pro- ducing Bacillus sp. on plant growth promoting activities. Journal of Advanced Microbiology, 2, 159-63.

Prajapati, K., Sharma, M.C., Modi, H.A. (2013). Growth promoting effect of potassium solubilizing microorganisms on okra (Abelmoscus esculentus). International Journal of Agriculture Science and Research, 1, 181-188.

Prazmowski, A. (1880). Untersuchung uber die Entwickelungsgeschichte und Fermentwirking einiger Bacterin-Arten Inaugural Dissertation. Hugo Voigt Leipiz, Germany.

Rahman, S.S., Siddique, R., Tabassum, N. (2017). Isolation and identification of halotolerant soil bacteria from coastal Patenga area. BMC Research Notes, 10, 531. https://doi. org/10.1186/s13104-017-2855-7

Raghavendra, M.P., Nayaka, N.C., Nuthan, B.R. (2016). Role of rhizosphere microflora in potassium solubilization. In V.S. Meena et al., (eds) Potassium solubilizing microorganisms for sustainable agriculture. (pp. 43-59). https://doi. org/10.1007/978-81-322-2776-2_4

Saravanan, V.S., Kumar, M.R., Sa, T.M. (2011). Microbial zinc solubilization and their role on plants. In D.K. Maheshwari (eds) Bacteria in Agrobiology: Plant Nutrient Management, (pp. 47-63). https://doi.org/10.1007/978-3-642-21061-7_3

Schwyn, B. \& Neilands, J.B. (1987). Universal CAS assay for the detection and determination of siderophores. Analytical Biochemistry, 160, 47-56. https://doi.org/10.1016/00032697(87)90612-9

Sheng, X.F. \& He, L.Y. (2006). Solubilization of potassiumbearing minerals by a wild-type strain of Bacillus edaphicus and its mutants and increased potassium uptake by wheat. Canadian Journal of Microbiology, 52, 66-72. https:// doi.org/10.1139/w05-117

Shrivastava, U.P. \& Kumar, A. (2011). A simple and rapid plate assay for the screening of indole 3 -acetic acid (IAA) producing organisms. International Journal of Applied Biology and Pharmaceutical Technology, 2, 120-123.

Sparks, D.L. (1987). Potassium dynamics in soil. Advances in Soil Science, 6, 1-63. https://doi.org/10.1007/978-1-46124682-4_1

Sugumaran, P. \& Janarthanam, B. (2007). Solubilization of potassium containing minerals by bacteria and their effect on plant growth. World Journal of Agricultural Science, 3(3), 350-355.

Tank, N. \& Saraf, M. (2010). Salinity-resistant plant growth promoting rhizobacteria ameliorates sodium chloride stress on tomato plants, Journal of Plant Interactions, 5(1), 51-58. https://doi.org/10.1080/17429140903125848

Uchida, R. (2000). Essential nutrients for plant growth: Nutrient functions and deficiency symptoms. In J.A. Silva, and R. Uchida (eds.) Plant Nutrient Management in Hawaii's soils, Approaches for Tropical and Subtropical Agriculture, (pp: 31-55).

Zahedi, H. (2016). Growth-promoting effect of potassiumsolubilizing microorganisms on some crop species. In: V.S. Meena et al., (eds.) Potassium solubilising microorganisms for sustainable agriculture (pp. 31-42). https://doi. org/10.1007/978-81-322-2776-2_3

Zhao, L., Xu, Y., Lai, X. (2018). Antagonistic endophytic bacteria associated with nodules of soya bean (Glycine max L.) 
and plant growth-promoting properties. Brazilian Journal of Microbiology, 49, 269-278. https://doi.org/10.1016/j. bjm.2017.06.007

Zhang, C. \& Kong, F. (2014). Isolation and Identification of potassium solubilising bacteria from tobacco rhizospheric soil and their effect on tobacco plants. Applied Soil Ecology, 82, 18-25. https://doi.org/10.1016/j.apsoil.2014.05.002 